University of Louisville

ThinkIR: The University of Louisville's Institutional Repository

Electronic Theses and Dissertations

$5-1922$

\title{
The effect of condensed, dry, and fresh milk in the diet of Albino rats.
}

John T. Walsh

University of Louisville

Follow this and additional works at: https://ir.library.louisville.edu/etd

\section{Recommended Citation}

Walsh, John T., "The effect of condensed, dry, and fresh milk in the diet of Albino rats." (1922). Electronic Theses and Dissertations. Paper 1506.

https://doi.org/10.18297/etd/1506

This Master's Thesis is brought to you for free and open access by ThinkIR: The University of Louisville's Institutional Repository. It has been accepted for inclusion in Electronic Theses and Dissertations by an authorized administrator of ThinkIR: The University of Louisville's Institutional Repository. This title appears here courtesy of the author, who has retained all other copyrights. For more information, please contact thinkir@louisville.edu. 


\title{
UN IVERS ITY OF LOUTSVILIE
}

The Effect of Condensed, Dry, and Fresh Milk

- In the Diet of Albino Rats.

\author{
A Dissertation, \\ Submitted to the Faculty \\ of the Graduate School of Arts and Sciences \\ In Partial Fulfiliment of the \\ Requirements for the Degree \\ of Master of Science
}

Department of Chemistry

By

John T. Walsh 
INTRODUCTION

11583 


\section{Introduction.}

Although much work has been done in determining the nutritional values of different milks, all of $1 t$ has been carried on at different times by various men, and there is no published data demonstrating the relative values dirived from experiments which were carried on simultaneously and in which all subjects were under the same conditions.

It is well known that rats show the effect of conditions to which they are subjected very easily and respond to them in the same manner in which man does. They are therefore a fit subject for nutritional experimentation.

The Albino rat lives three years as compared to man's ninety, the body composition and that of the urine being the same per centage as that of man. Therefore multiplying results by thirty gives the data for man, assuming that the normal span of man's life is ninety years.

The purpose of this paper therefore will be to show the relative nutritional value of different milks as found by simultaneous experiments with Albino rats subjected to the same environment. 
REFERBNCES 
References.

Chemical Abstracts, Vol. 14, No. 11.

Thomas B. Osborne and Lafayette B. Mendel

find that milk is not a good source for water soluble vitamine.

Journal American Medical Association, May 28, 1921.

M. Roseneau states that milk is rich in $A$ and $B$ antiscorbutic vitamines, that it is unusually $\mathrm{rich}$ in vitamine $A$, contains abundant amount of $B$ and $a$ variable but usually sufficlent amount of antiscorbutic. He further states that dry milk retains its antiscorbutic property but loses after exposure to air.

Journal American Medical Association, April 16, 1921.

Editorial. Vitamine content of milk depends on the vitamine content of the food given to the cow, and that summer milk contains more vitamine than winter milk, due to the above reason.

Journal American Medical Association, May 14, 1921.

E.R. Hart, H. Steenbock, and N.R. Ellis working on the antiscorbutic potency of milk powders find that powders vary, due to the method of drying and to the vitamine content of the initial milk.

Chemical Abstracts, Vol. 14, No. 18:

Hidesaburo Bekine found that white mice when fed condensed milk alone thrive well for one hundred days but finally suffer from polyneuritis and anemia. They find that condensed milk is lacking in water soluble vitamine and in iron content.

Chemical Abstracts, Vol. 4, No. 20.

C. Kellick, Millard and Leicester recommend aried milk as food for infants because of (1) ease of aigestion, (2) conservability, (3) bacterial purity, (4) cheapness (no waste), (5) convenience, (6) palatableness. Its disadvantages are of a theoretical nature and consist in the presumed destruction of the 
antiscorbutic properties of fresh milk. This, however, can be compensated by the administration of fruit juices.

Chemical Abstracts, Vol. 6, No. 22 .

A.W. Stewart analyzed sixty-seven dried milks and patent foods and considers the majority unsuited for infants on account of deficiency in fat and the large per centage of starch present, - the former causing rickets and the latter not being the proper form of carbohydrate for assimilation. Their mode of preperation also destroys the natural enzymes which are sald to possess antiscorbutic properties. None effectually replace human milk.

Chemlcal Abstracts, Vol. 12, Nol 22.

F.J.H. Coutts after experiments conducted on rats comes to the conclusion that dry milk is better than fresh milk and the evidence of the welght charts show that it has lost none of the characteristics of fresh milk; and he further states that its advantages over fresh milk are in its portability, keeping properties, especially dried skim milk,convenience, and freedom from waste and bacteria, and its economy.

Chemical Abstracts, Vol. 12, No. 22.

G. Winfield experimented with forty rats and found that normal health remained for a period of sixteen months but growth fell below normal when one half to two thirds adult weight was reached and only renewed by mixed diet. Tith children he finds that growth is normal and even above.

Chemical Abstracts, Vol. 10, No. 7.

S.B. Triner in reporting on methods of manufacturing and the uses of milk powder says that the methods are better than those used with condensed milk, and that they fill all milk wants.

Chemical Abstracts, Vol. 14, No. 9.

R.E. Barnes and E.M. Hume, after woring with guineas find that dry milk does not contain antiscorbutic vitamine. 
Chemical Abstracts, Vol. 14, No. 11.

Thomas B. Osborne and Lafayette B. Mendel find that milk is not a good source for water soluble vitamine and therefore dry milk is deficient in this vitamine.

Journal American Medical Association, May 14, 1921.

E.B. Hart, H. Steinbock, and N.R. Ellis state that milk powders vary, due to the method of drying and the vitamine content of the initial milk.

Chemical Abstracts, Vol. 4, No. 6 .

E.C. Averagnet and M. Behu, Hospitals Paris and Lyons, find that raw milk of good quality and quantity is an ideal nourishment. Alert vigilance is required in its production, transportation, and distribution.

Chemical Abstracts, Vol. 7, No. 14.

Philip Rupp in research on pasteurization of milk finds that it does not change the chemical composition unless ralsed to 160 degrees Fahrenhelt. Journal Blolngical Chemistry, Vol. 44, 1920.

H.A. Mattill and Ruth E. Conklin find that rats fed on only fresh cows' milk or only on dessicated cows' milk have a good inftial growth, but after the fiftieth to the hundredth day a decided reterdation is noted, and no reproduction takes place. The lack of growth is due to the dilute form of food, as better growth is noted with dry milk' and their average food consumption is considerably higher. The females are below normal at seventy-five days and aga in no reproduction takes place. The conclusion drawn is that milk is lacking both quantitatively and qualitatively in substances necessary for successful growth and reproduction, especially in the female, and it may contain substances that are inhibitory to the growth of an animal in the third or mature growth cycle. They find that fifty-five per cent dry milk, forty per cent starch, five per cent butter fat produces practically normal growth, but no reproduction takes place. 
Soclety of Blology and Medicine. Proceedings, 1919-20, Vol. 17 , No. 9 .

H.C. Sherman, M.E. Rouse, B. Allen, E. Woods find that when rats are fed on milk and bread in which the milk is one fifth of the total number of calories, the young rats made normal growth, but females usually falled to breed and no young were raised. Tith whole wheat bread young were suckled at the cost of considerable loss in weight of the mother and grew at less than the normal rate.

Journal of Hygiene, 1909, Vol. 60, p. 233.

Lane Claypon finds that rats make more rapid gain when fed on dry milk than upon bolled, and these in turn more rapid than those fed on raw milk with bread as part of the ration.

Great Britain Local Board Food Rep. 1918, Vol.24,p.139.

G. Winfield fed rats exclusively on dry milk and found growth in both sexes below normal when one half to two thirds adult weight was reached and renewed only when a mixed dietary was put in place of dry milk. No data was given on reproduction. 
Experimental. 
The rats used in these experiments were descendents of three palrs of normal rats which had been fed on fresh, dry, and condensed milks, respectively, three weeks previous to breeding. The young were separated when four weeks old and given all the food of their respective diets that they could eat. Their weights were taken weekly, pictures were taken at regular intervals, and all changes in appearance were carefully noted.

The rats were all subjected to the same environment and placed in individual and sanitary cages. The amount of food given was determined by the amount eaten the previous day, care being taken to give each rat all it could eat.

Rat No. I, which had been fed on fresh milk, bore eleven young, which when separated were fed on the following diets:

Rat I, No. I A - - fresh milk and bread Rat I, No. I a - - fresh milk and bread Rat I, No. I B - - dry milk and bread Rat I, No. I b - - dry milk and bread Rat I, No. I C - - condensed milk and bread Rat I, No. I c - - condensed milk and bread Rat I, No. I D - Mellins food, bread, and water Rat I, No. I E - Mellins food, bread, water, and. orange juice

Rat I, No. I F - - fresh milk, bread, and orange juice. 
Rat No. II, which had been fed on dry mille, bore six young which were fed as follows:

Rat II, No. II a - - bread and fresh.milk Rat II, No. II b - - bread and dry milk Rat II, No. II c - - dry milk paste.

Rat No. III, fed on condensed milk, bore nine young which were separated and fed the following:

Rat III, No. III A - - fresh milk and bread Rat III, No. III b - - dry milk and bread Rat III, No. III C - - condensed milk and bread Rat III, No. III c - - condensed milk and bread Rat III, No. III D - condensed milk, bread and orange juice

Rat III, No. III d - condensed milk, bread and orange juice

Rat III, No. III E - Mellins food, bread, and water

Rat III, No. III e - Mellins food, bread, and water

Rat III, No. III f - - Mellins food, bread, water and orange juice.

The liter obtained from Rat I, two of which died before the twenty-fifth day, appeared scrubby; those from Rat II, three of which died before the date of separation, were large; while those from Rat III were small and nervous; no death occurred, however.

The weights of all rats fed on the same diet will be given on the same page, comparison being made by means of charts and pictures showing the best rat obtalned from each diet. 
Fresh Milk.

Rat II,No.IIa. Rat I,No.IA. Rat I,No.Ia. Rat III,No.IIIA Male Female



54.6
74.7
85.0
101.7
115.1
129.7
132.8
134.9
144.5
144.7
144.9
148.5
155.5
163.1
163.4
162.4
165.7
168.8
172.7
175.3
178.0
180.8
186.9
185.0
180.7
180.7
186.5
191.8
195.5
192.3

32.4

40.4

50.0

62.2

72.1

76.6

85.0

97.7

Fema le

Ma le

103.6

110.0

112.9

114.0

125.0

126.7

130.9

135.0

138.3

143.3

149.3

32.0

23.5

34.0

42.4

46.0

55.1

65.5

64.8

74.2

83.1

95.0

108.6

88.9

114.7

113.2

115.7 .

122.4

126.9

134.3

142.5

146.7

150.0

148.5

160.0

161.9

165.2

156.5

157.5

164.5

165.2

165.0

$*$

100.0

110.2

116.5

122.0

133.1

154.8

170.0

184.8

196.3

202.9

206.6

219.2

217.8

220.0

234.3

250.0

252.1

262.3

262.0

262.2

246.4

267.0

270.0

(1) Bred with Rat I for two weeks.

* Weights absent due to breeding, January 22 , nine young. 
Rat II,No.IIb. Rat I,No.Ib. Rat I,No.IB. Rat III,No.IIIb Male Male Male Female



Dec. $5 \quad 184.0$

" 12185.7

" $19 \quad 181.2$

" $26 \quad 185.3$

Jan. 2210.0

" 9210.0

" $16 \quad 203.4$

" 23198.8

" $30 \quad 199.0$

Feb. 6201.8

" 13208.8

" 20210.0

32.5
39.7
47.6
51.0
52.9
60.0
70.3
86.5
95.0
108.3
116.0
136.4
162.0
171.4
169.7
171.1
183.5
182.0
181.1
176.7
169.4
172.2
193.9
203.0
205.8
207.4
213.4
193.0
205.0
209.0

30.2
39.0
42.1
50.2
55.0
64.7
74.2
91.6
96.4
110.6
120.1
134.4
156.9
160.0
160.0
165.0
179.4
184.8
188.1
193.6
186.0
184.2
210.5
205.8
203.4
203.6
208.4
195.6
206.5
210.5

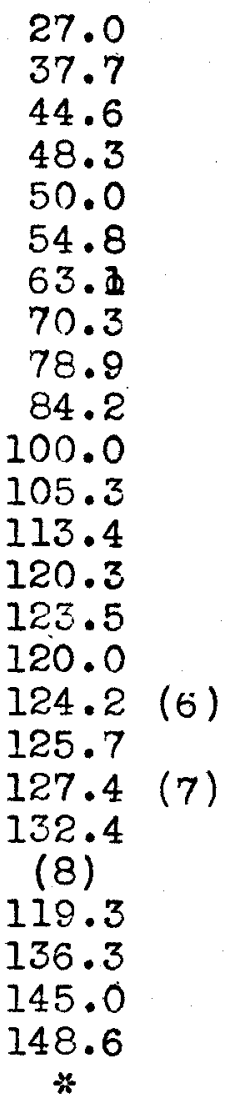

27.0

44.6

48.3

50.0

54.8

63.1

70.3

78.9

84.2

100.0

105.3

113.4

120.3

123.5

(6) $\quad 179.4$

120.0

124.2

125.7

(3)

(6)

(7)

(4)

(8)

119.3

136.3

145.0

$*$

(1) Bred with Rat II, No. II c during day, separated at night.

(2) Bred with Rat II, No. II c all day for two weeks.

(3) Bred with Rat III, No. III b all day for one week.

(4) Bred with Rat III, No. III b all day for two weeks.

(5) Bred with Rat III, No. III b all day for two weeks.

(6) Bred with Rat I, No. I B all day for one week.

(7) Bred with Rat I, No. I B all day for two weeks.

(8) Bred with Rat I, No. I B all day for two meelss.

(9) Bred with Rat II for two weeks.

* January 30, six young. 
Bread and Condensed Milk

Rat I,No. IC. Rat I,No. Ic. Rat III,No.IIIC. Rat III,No.IIIC. Nale Female

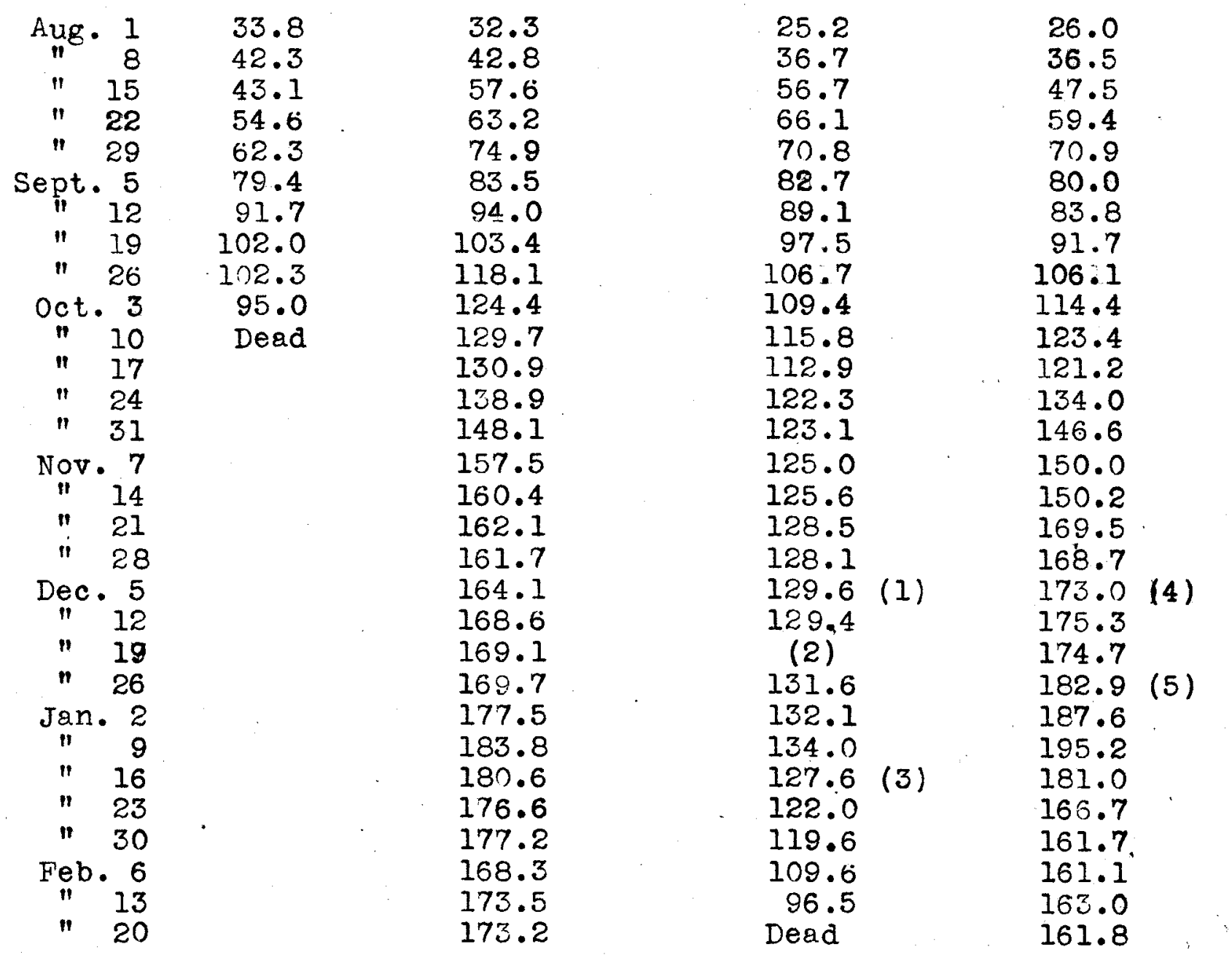

(1) Bred with Rat III, No. III c one week.

(2) Bred with Rat III, No. IIf c two weeks.

(3) Bred with Rat III two weeks.

(4) Bred with Rat III, No. ItI C one week.

(5) Bred with Rat III, No. III c two weeks. 
Bread, Condensed Milk, and Orange Juice.

Rat III,No. ITID. Rat III,No.IIId Male Male

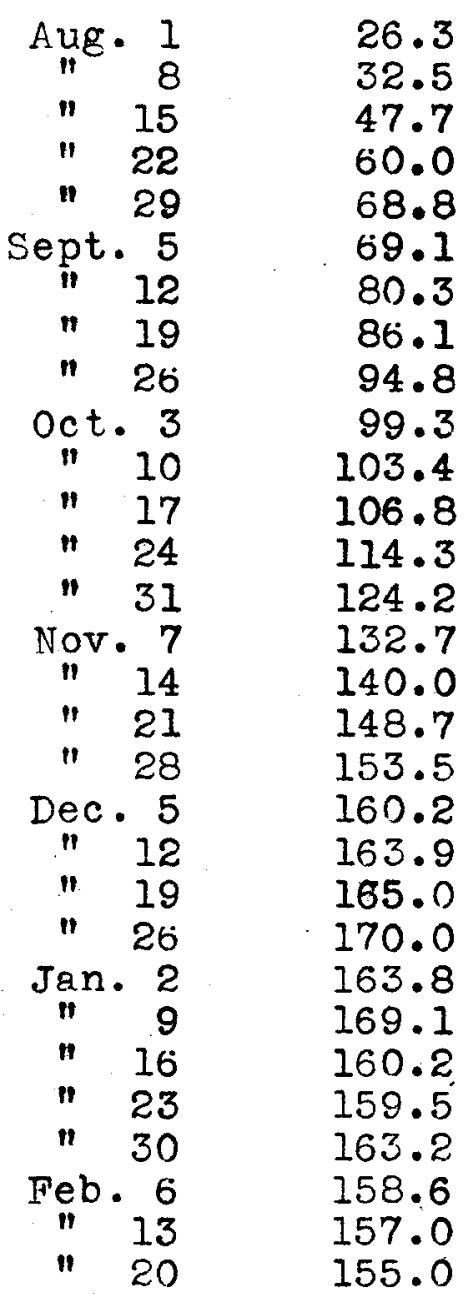

25.4

34.8

45.6

58.9

69.4

79.2

89.2

94.2

101.0

110.9

111.2

97.8

96.0

89.5

80.7

Dead
Bread, Fresh Milk, and Orange Juice.

\author{
Rat I, No.If \\ Female
}

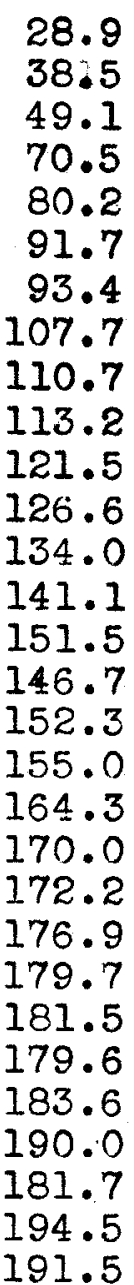

49.1

70.5

80.2

91.7

93.4

107.7

110.7

113.2

121.5

126.6

134.0

151.5

146.7

152.3

155.0

164.3

170.0

172.2

176.9

179.7

181.5

179.6

183.6

190.0

181.7

191.5 
Mellins Food, Bread, and Water

Rat I, No. ID Rat IIT, No. IIIE Rat III, No. IIIe Male Male Male

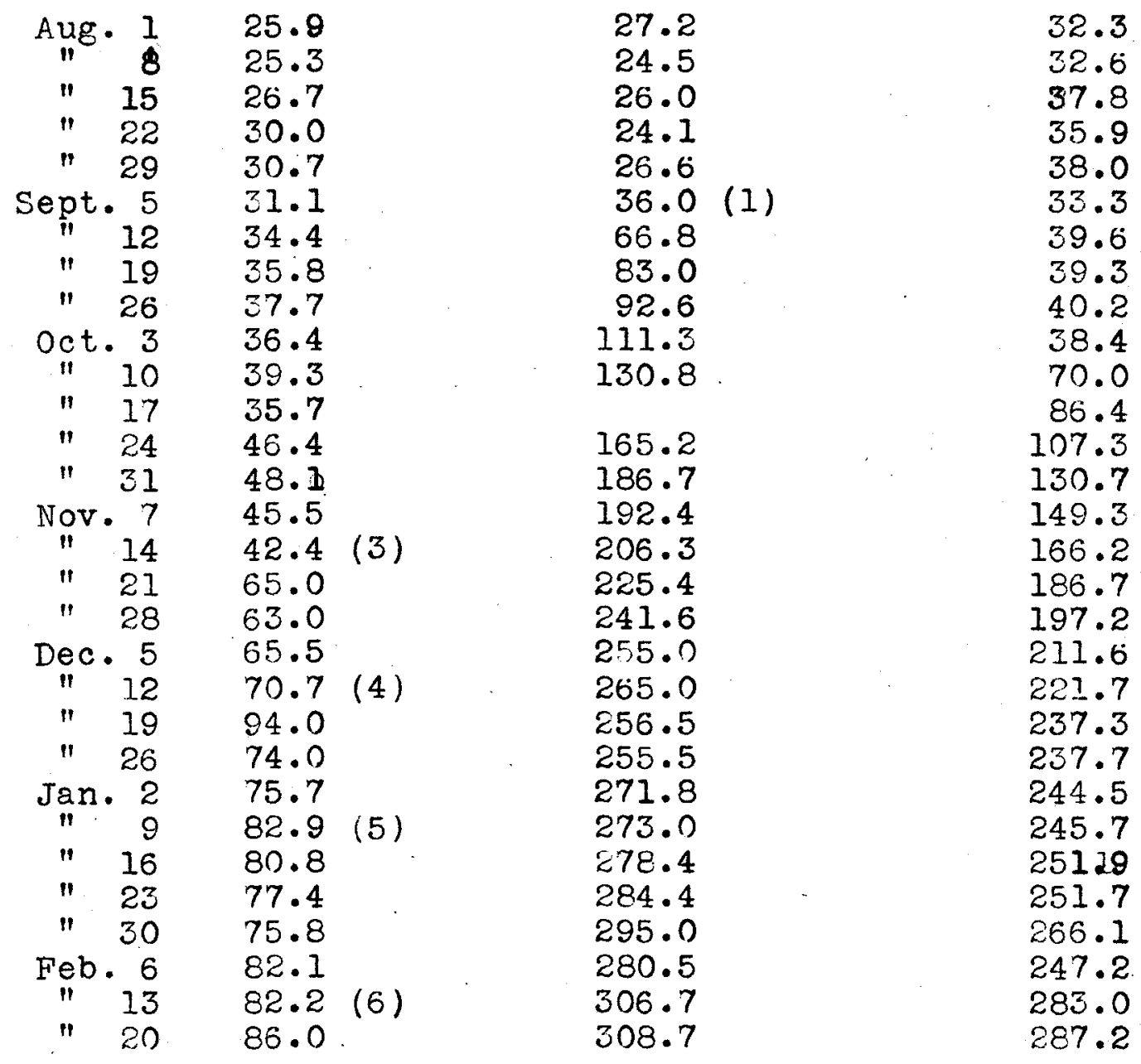

(1) Diet changed to Mellins Food, Bread, and Milk.

(2) Diet changed to Melins Food, Bread, and Milk.

(3) Ilet changed to Mellins Food, Bread, and Milk for three days, then back to Nater.

(4) Diet changed as in (3).

(5) Diet changed as in (3).

(6) Diet changed as in (3). 
Mellins Food, Bread, Water, and Orange Julce.

$$
\text { Rat } \underset{\text { Male No. I E. Rat IIT, No. III f. }}{\text { Male }}
$$

$$
\begin{array}{cr}
\text { Aug. } & 1 \\
" \text { " } & 15 \\
" & 22 \\
\text { " } & 29 \\
\text { sept. } 5 \\
\text { " } & 12 \\
\text { " } & 19 \\
\text { " } & 26 \\
\text { oct. } & 2 \\
\text { " } & 9
\end{array}
$$

27.2
28.0
28.3
Dead
24.8

22.4

25.7

26.5

29.7

28.7

84.5

35.5

38.0

34.9

Dead 


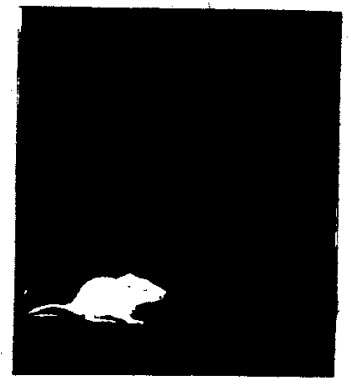

NORMAL RAT $A G E$

FIVE WEEKS

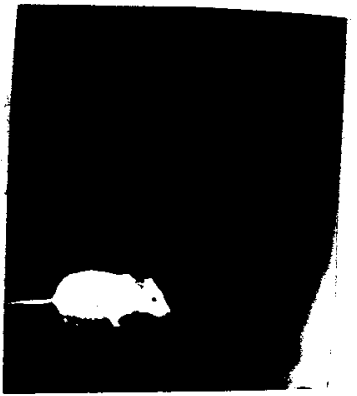

DEEICIEUTIDIET AGE

THIRTYFIVE WEEKS

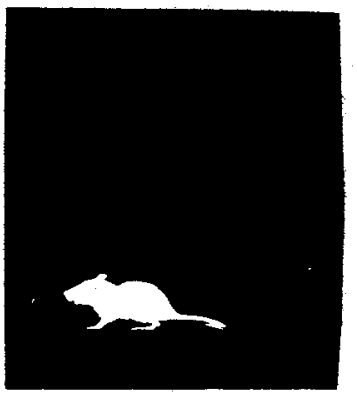

NORMAL RAT $A G E$ FIVE WEEKS

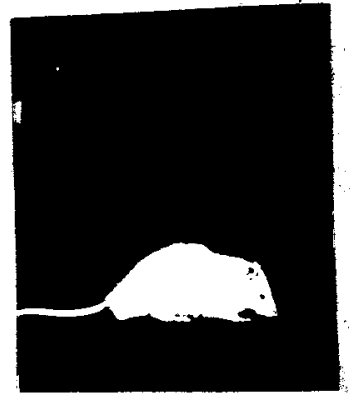

NORMAL DIET AGE

THIRTYFIVE WEEKS

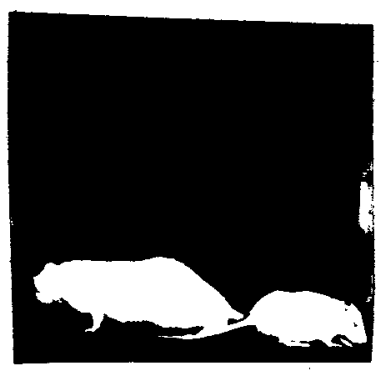







(1)

I

I


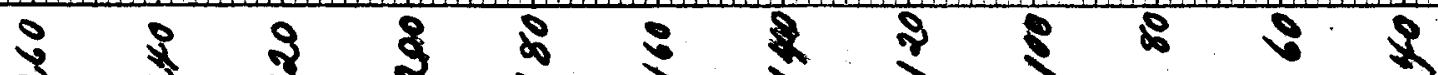



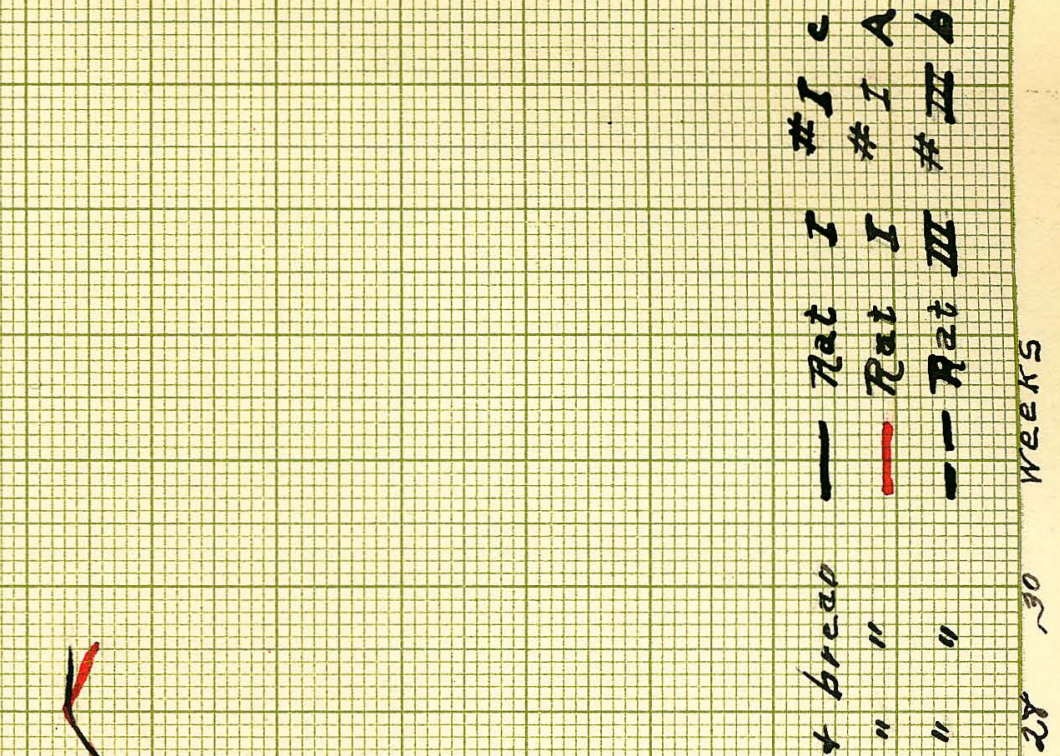

$z=: 2$
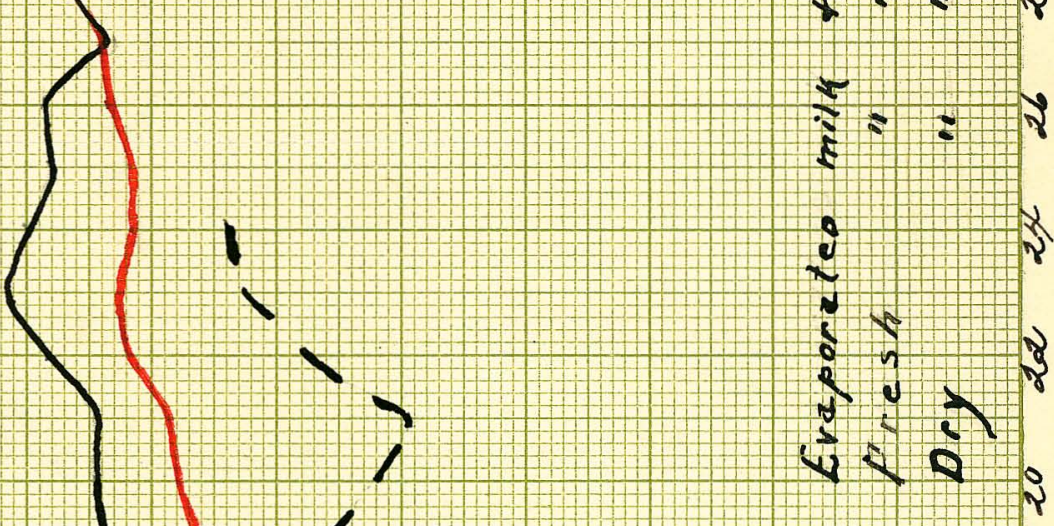

I
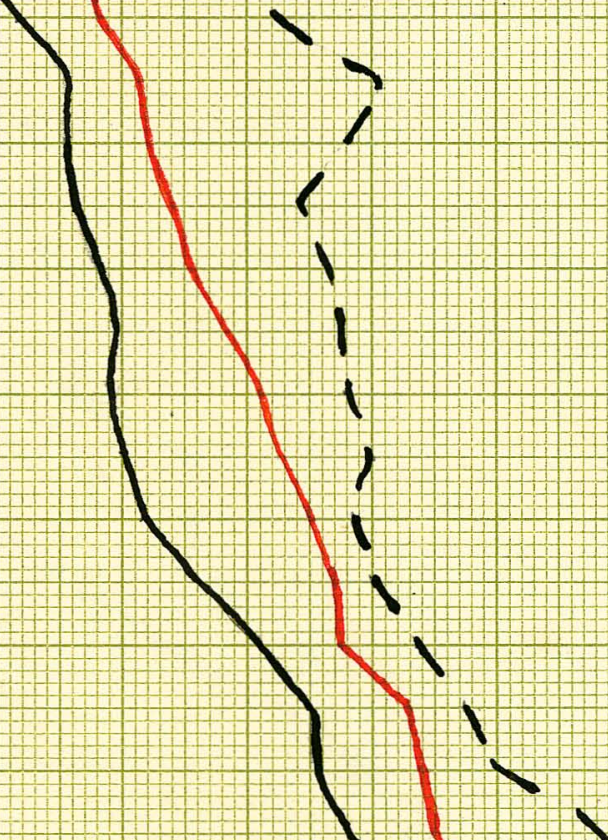

o

2

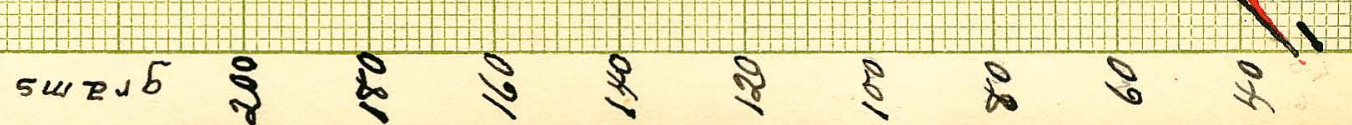


CONC LUS ION. 
The results as shown in the charts demonstrate quite plainly the relative nutritional value of the respective diets; it can be stated in addition, however, that the rats fed on dried milk were more susceptible to cold than those fed on fresh milk, and the fecundity of the former is lower than that of the latter.

The rats maintained on evaporated milk grew more slowly, and in only one case was greater weight attained. These rats were most susceptible to disease, and greater mortality resulted.

The curves resulting from plotting a det containing vitamines in what might be termed excess or at least in abundance show a steadier rise to normal adult weight than in any other case, thus proving the benefit derived from the vitamine content in the diet.

The result obtained from experimenting with a diet consisting of Mellins food, bread and water gives the result one would expect of a diet that contains little tis sue replacing elements. The repld growth evidenced when the diet was 
changed to include fresh milk conflema the

belief that normal weight and health are

maintained only by a well balanced diet rich in vitamines. 